\title{
PEMBERIAN SARI KURMA DAPAT MENINGKATKAN KADAR HB PADA IBU
}

\author{
Dainty Maternity ${ }^{1 *}$, Auda Audrias ${ }^{2}$, Dewi Yuliasari ${ }^{3}$, Ana Mariza $^{4}$ \\ 1,2,4Program Studi DIV Kebidanan Universitas Malahayati \\ 3Program Studi DIII Kebidanan Universitas Malahayati \\ *Korespondensi email denty.mf@gmail.com
}

\section{ABSTRACT GIVING DATE CREAM CAN INCREASE HB LEVELS IN MOTHERS}

Background Anemia in pregnancy is a maternal condition with hemoglobin values below $11 \mathrm{~g} / \mathrm{dl}$ in the first and third trimesters, or hemoglobin levels less than $10 \mathrm{~g} / \mathrm{dl}$ in the second trimester. Data on visits by pregnant women at Independent Practice Midwife Betty, Amd. Keb Based on a pre-survey conducted at BPS Okdiah Betty Amd. Keb Kec. Trimurjo Kab. Central Lampung, by looking at the visit data of pregnant women TM I-TM II for the last 3 months as many as 67 people, with the results of HB 8.0-10.0 examination with mild anemia category as many as 26 pregnant women (38.8\%), and HB 10.1-13.0 with normal category as many as 14 people (20.9\%), from the overall data it can be seen if there are 27 people (40.2\%) who did not do Hb checks during pregnancy.

The purpose of this study was to determine the effect of giving date palm juice on increasing HB levels in pregnant women in the Independent Practice of Midwife Okdiah Betty, Amd. Keb Kec. Trimurjo Kab. Lampung in the middle of 2021..

Methods This type of research is quantitative, the research design is pre-experimental method with a one group pretest - posttest design approach. Data on visits by pregnant women at Independent Practice Midwife Betty, Amd. Kec. Trimurjo Kab. Central Lampung, obtained the number of pregnant women TM I and III during the last 3 months as many as 67 people, purposive sampling technique., univariate and bivariate data analysis using t-test

Result The average HB level in pregnant women before being given date palm juice with a mean of 10 , $270 \mathrm{gr} / \mathrm{dl}$, a min value of $9.3 \mathrm{gr} / \mathrm{dl}$ and a max value of $10.8 \mathrm{gr} / \mathrm{dl}$. The average $\mathrm{Hb}$ level at week 7 with a mean of $10.480 \mathrm{gr} / \mathrm{dl}$, a min value of $9.7 \mathrm{gr} / \mathrm{dl}$ and a max value of $11.0 \mathrm{gr} / \mathrm{dl}$, and a $\mathrm{Hb}$ at week 14 with a mean of $10,807 \mathrm{gr} / \mathrm{dl}$, a min value of $10.2 \mathrm{gr} / \mathrm{dl}$ and a max $11.2 \mathrm{gr} / \mathrm{dl}$.

Conclusion there is an effect of giving date palm juice to increase $\mathrm{Hb}$ levels in pregnant women Suggestion Conducting outreach to the community as a form of promotional and preventive efforts to overcome and minimize the incidence of anemia.

Keywords: Dates Extract, Hb Level, Pregnant Women

\section{ABSTRAK}

Latar Belakang Anemia dalam kehamilan merupakan suatu kondisi ibu dengan kadar nilai hemoglobin di bawah $11 \mathrm{gr} / \mathrm{dl}$ pada trimester satu dan tiga, atau kadar hemoglobin kurang dari $10 \mathrm{gr} / \mathrm{dl}$ pada trimester dua. Data Kunjungan ibu hamil di Praktik Mandiri bidanokdiah Betty, Amd. Keb Berdasarkan prasurvey yang dilakukan di BPS Okdiah Betty Amd.Keb Kec.Trimurjo Kab.Lampung Tengah, dengan melihat data kunjungan ibu hamil TM ITM II selama 3 bulan terakhir sebanyak 67 orang,dengan hasil pemeriksaan HB 8,0-10,0 dengan kategori anemia ringan sebanyak 26 ibu hamil (38,8\%),dan HB 10,1-13,0 dengan kategori normal sebanyak 14 orang $(20,9 \%)$,dari data keseluruhan dapat diketahui jika terdapat 27 orang $(40,2 \%)$ yang tidak melakukan pemeriksaan $\mathrm{Hb}$ saat hamil. Tujuan penlitian ini diketahuipengaruh pemberian sari kurma terhadap peningkatan kadar $\mathrm{HB}$ pada ibu hamildi Praktik Mandiri Bidan Okdiah Betty, Amd. Keb Kec.Trimurjo Kab.Lampung tengahtahun 2021.

Metode Jenis penelitian kuantitatif, desain penelitian metode Pra Eksperimental dengan pendekatan one group pretest - posttest design. Data Kunjungan ibu hamil di Praktik Mandiri bidanokdiah Betty, Amd. Kec.Trimurjo Kab.Lampung Tengah, didapat jumlah ibu hamil TM I dan III selama 3 bulan terakhir sebanyak 67 orang, teknikpurposive sampling., analisa data univariat dan bivariat menggunakan t-test

Hasil Rata-rata kadar HB pada ibu hamilsebelum diberi sari kurma dengan Mean10, 270gr/dlnilai min 9,3gr/dl dan nilai max 10,8gr/dl.Rata-rata kadar $\mathrm{Hb}$ minggu ke 7 dengan Mean10,480gr/dlnilai min 9,7gr/dl dan nilai max 11,0gr/dl, dan $\mathrm{Hb}$ minggu ke 14 dengan Mean10,807gr/dlnilai min 10,2gr/dl dan nilai max 11,2gr/dl. Kesimpulan terdapat pengaruh pemberian sari kurma terhadap peningkatan kadar $\mathrm{Hb}$ pada ibu 


\section{JKM (Jurnal Kebidanan Malahayati),Vol 7,No.4.Oktober 2021, ISSN (Print) 2476-8944 ISSN (Online) 2579-762X, Hal 772-779}

Saran Melakukan penyuluhan kepada masyarakat sebagai bentuk upaya promosi dan preventif untuk menanggulangi dan meminimalkan angka kejadian anemia.

Kata Kunci : Sari Kurma, Kadar Hb, Ibu Hamil

\section{PENDAHULUAN}

Cakupan pemberian TTD pada ibu hamil di Indonesia tahun 2018 adalah 81,16\%. Angka ini belum mencapai target Renstra tahun 2018 yaitu 95\%. Provinsi dengan cakupan tertinggi pemberian TTD pada ibu hamil adalah Bengkulu (99,49\%), sedangkan provinsi dengan cakupan terendah adalah Banten (32,11\%), sedangkan Lampung dengan persentase $90,0 \%$ yang artinya masih kurang dari 95\% (Kemenkes RI, 2018).

Anemia merupakan suatu keadaan adanya penurunan kadar hemoglobin, hematokrit dan jumlah eritrosit dibawah nilai normal. Pada penderita anemia, lebih sering disebut kurang darah, kadar sel darah merah (hemoglobin) dibawah nilai normal. Penyebabnya bisa karena kurang zat gizi untuk pembentukan darah, misalnya zat besi, asam folat dan vitamin B12. Tetapi yang sering terjadi adalah anemia karena kekurangan zat besi (Rukiyah, 2019).

Anemia dalam kehamilan merupakan suatu kondisi ibu dengan kadar nilai hemoglobin di bawah $11 \mathrm{gr} / \mathrm{dl}$ pada trimester satu dan tiga, atau kadar hemoglobin kurang dari $10 \mathrm{gr} / \mathrm{dl}$ pada trimester dua. Darah akan bertambah banyak dalam kehamilan yang lazim disebut Hidremia atau Hipervolemia. Akan tetapi bertambahnya sel darah kurang dibandingkan dengan bertambahnya plasma sehingga terjadi pengenceran darah. Perbandingan tersebut adalah sebagai berikut: plasma 30\%, sel darah 18\%, dan hemoglobin 19\%. Ibu hamil umumnya mengalami defisiensi besi sehingga hanya memberi sedikit zat bezi pada janin yang di butuhkan untuk metabolism besi yang normal.Kekurangan zat besi dapat menimbulkan gangguan atau hambatan pertumbuhan janin baik sel tubuh maupun sel otak (R. D. Rahayu, 2017).

Berdasarkan hasil Analisis Survey Demografi Kesehatan Indonesia (SDKI) 2012 Angka Kematian Ibu (AKI) di Indonesia masih tinggi yaitu 359/100.000 KH.Penyebab utama kematian ibu secara langsung adalah perdarahan $28 \%$, eklampsia $24 \%$, dan infeksi $11 \%$. Penyebab secara tidak langsung adalah anemia 51\% (Profil Dinas Kesehatan Provinsi Lampung,2017; Yuliasari 2017)

Penyebab terbanyak anemia defisiensi zat besi yaitu karena rendahnya masukan zat besi yang berasal dari makanan, serta rendahnya tingkat penyerapan zat besi dari makanan. Rendahnya tingkat penyerapan zat besi disebabkan oleh komposisi menu makanan masyarakat yang lebih banyak mengandung faktor - faktor yang dapat menghambat penyerapan zat besi seperti serat, fitat, maupun tannin (Wasnidar, 2013).

Upaya yang dilakukan dalam pencegahan dan penanggulangan anemia ada dua yaitu farmakologi dengan mengkonsumsi tablet Fe Selain terapi farmakologi dapat juga diberikan terapi non farmakologi. Pencegahan anemia dapat dilakukan dengan cara mengkonsumsi makanan yang banyak mengandung zat besi. Salah satunya adalah kacang merah. Kacang merah merupakan salah satu makanan yang tinggi serat. Kandungan mineral, seperti zat besi, zinc, dan tembaga pada kacang merah bermanfaat membantu pembentukan sel darah merah, enzim, dan tulang (Umrah, 2018).

Pemberian zat besi kepada ibu hamil yang dianjurkan adalah minimal 90 butir selama kehamilannya dan pemberian ini biasanya diberikan secara bertahap serta paling baik diberikan pada trimester III (umur kandungan lebih dari 7 bulan). Kebanyakan anemia yang di derita masyarakat adalah karena kekurangan zat besi yang dapat diatasi melalui pemberian zat besi secara teratur dan peningkatan gizi.selain itu di daerah pedesaan banyak dijumpai ibu hamil dengan mal nutrisi atau kekurangan gizi,ibu hamil dengan pendidikan tingkat sosial ekonomi rendah (Manuaba2014 ; Maternity,2014)

Sari kurma merupakan kurma yang dihaluskan dan diambil sarinya, berbentuk cair, kental, berwarna hitam dan terasa manis serta mengandung zat gizi yang lengkap seperti buah kurma. Dengan kandungan yang lengkap, diharapkan sari kurma dapat meningkatkan kadar hemoglobin ibu hamil (Widowati, 2019).

Kurma mengandung karbohidrat tinggi sehingga dapat menyediakan energi yang cukup. Sebagian kandungan gulanya terdiri atas glukosa, fruktosa, dan sukrosa, Menurut data kementerian kesehatan haji menjelaskan bahwa kadar zat besi dalam buah kurma juga cukup tinggi yaitu $0,90 \mathrm{mg} / 100 \mathrm{~g}$ buah kurma ( $11 \% \mathrm{AKG})$, dimana zat besi menjadi salah satu komponen dalam darah untuk membawa oksigen dalam darah, untuk menjaga keseimbangan zat besi dalam tubuh, sehingga mengurangi resiko terjadinya perdarahan pada ibu hamil (Diyah, 2017). 
Kurma mengandung zat besi yang tinggi sehingga membantu meningkatkan kadar hemoglobin dan mencegah anemia, dengan mengkonsumsi kurma sebanyak 25 gr/hari/orang selama 30 hari dapat meningkatkan kadar hemoglobin pada ibu hamil karna dalam $25 \mathrm{gr}$ kurma mengandung 0,225 zat besi (Eny,dkk, 2016).Kurma merupakan salah satu buah yang mengandung zat besi (fe) yang cukup mencukupi kebutuhan zat besi,vitamin C,vitamin B kompleks dan asam folat yang dapat membantu pembentukan sel darah merah ,zat besi merupakan bagian dari molekul hemoglobin,dengan berkurangnya zat besi maka sintesis hemoglobin akan menurun dan menyebabkan kadar hemoglobin menurun (Arum Sari,Eti Poncorini Pamungkasari \& Yulia Lanti Retno Dewi 2018)

Data Kunjungan ibu hamil di Praktik Mandiri BidanOkdiah Betty, Amd. Keb Berdasarkan prasurvey yang dilakukan di BPS Okdiah Betty Amd.Keb Kec.Trimurjo Kab.Lampung Tengah, dengan melihat data kunjungan ibu hamil TM I-TM II selama 3 bulan terakhir sebanyak 67 orang,dengan hasil pemeriksaan HB 8,0-10,0 dengan kategori anemia ringan sebanyak 26 ibu hamil $(38,8 \%)$,dan HB 10,1-13,0 dengan kategori normal sebanyak 14 orang $(20,9 \%)$,dari data keseluruhan dapat diketahui jika terdapat 27 orang $(40,2 \%)$ yang tidak melakukan pemeriksaan $\mathrm{Hb}$ saat hamil.

Berdasarkan hasil observasi dan wawancara bebas terpimpin terhadap 7 ibu hamil di Praktik Mandiri Bidan Okdiah Betty A.md Keb dimana 5 orang ibu mengalami anemia ringan dengan $\mathrm{HB}$ 9,5-10,8 gr/dl, sedangkan 2 ibu mengalami anemia sedang yaitu 8,8 dan 9,2 gr/dl, setelah dilakukan wawancara terhadap 2 ibu, didapat hasil jika ibu mengalami anemia dikarenakan tidak rutin mengkonsumsi tablet Fe dan sering mengkonsumsi teh setelah minum tablet $\mathrm{Fe}$ untuk menghilangkan mual muntah akibat konsumsi tablet Fe peneliti tertarik melakukan penelitian dengan judul "Pengaruh Pemberian Sari Kurma Terhadap Peningkatan Kadar HB Pada lbu Hamildi Praktik Mandiri BidanOkdiah Betty A.md Keb Kec.Trimurjo Kab.Lampung Tengah.

\section{METODE PENELITIAN}

Dalam penelitian ini penulis menggunakan jenis penelitian kuantitatif, desain penelitian metode Pra Eksperimental dengan pendekatan one group pretest - posttest design.Data Kunjungan ibu hamil di Praktik Mandiri BidanOkdiah Betty, Amd. Kec.Trimurjo Kab.Lampung Tengah, didapat jumlah ibu hamil TM I dan III selama 3 bulan terakhir sebanyak 67 orang, teknikpurposive sampling.

\section{HASIL DAN PEMBAHASAN \\ Karakteristik Responden \\ Tabel 1. \\ Karakteristik Ibu Hamil di Praktik Mandiri \\ BidanOkdiah Betty, Amd. Keb Kec.Trimurjo Kab.Lampung Tengah Tahun 2021}

\begin{tabular}{lcc}
\hline \multicolumn{1}{c}{ Karakteristik } & Frekuensi & $\begin{array}{c}\text { Persentase } \\
(\%)\end{array}$ \\
\hline Usia & & \\
$<\quad 20$ dan > 35 & 6 & 20,0 \\
Tahun & 24 & 80,0 \\
20-35 Tahun & & \\
Usia Kehamilan & 12 & 40,0 \\
TM I & 18 & 60,0 \\
TM II & & \\
IMT & 21 & 70,0 \\
IMT Ideal & 9 & 30,0 \\
IMT Tidak Ideal & & \\
Pendidikan & 25 & 83,3 \\
Pendidikan Tinggi & 5 & 16,7 \\
Pendidikan Rendah & 5 & \\
Pekerjaan & & 50,0 \\
lbu Tidak Bekerja & 15 & 50,0 \\
lbu Bekerja & 15 & 100 \\
\hline \multicolumn{1}{c}{ Total } & 30 & \\
\hline
\end{tabular}

Dari tabel diatas dapat diketahui karakteristik ibu hamil di Praktik Mandiri BidanOkdiah Betty, Amd. Keb Kec.Trimurjo Kab.Lampung Tengah Tahun 2021, dengan melihat usia terbanyak adalah usia 20-35 tahun sebanyak 24 responden $(80,0 \%)$, usia kehamilan terbanyak adalah TM ॥ 15-27 Minggu sebanyak 18 responden $(60,0 \%)$ IMT terbanyak adalah IMT Ideal 21 responden $(70,0 \%)$, pendidikan terbanyak adalah pendidikan tinggi (SMA-Perguruan Tinggi) sebanyak 25 responden $(83,3 \%)$ dan pekerjaan rata-rata bekerja 15 responden $(50,0 \%)$.

Dari tabel diatas dapat diketahui karakteristik ibu hamil di Praktik Mandiri BidanOkdiah Betty, Amd. Keb Kec.Trimurjo Kab.Lampung Tengah Tahun 2021, dengan melihat usia terbanyak adalah usia 20-35 tahun sebanyak 24 responden $(80,0 \%)$ dengan mean hari ke 1 10,275gr/dL hari ke 7 10,942gr/dL hari ke $1410,804 \mathrm{gr} / \mathrm{dL}$, usia kehamilan terbanyak adalah TM II 15-27 Minggu sebanyak 18 responden $(60,0 \%)$ dengan mean hari ke 1 $10,278 \mathrm{gr} / \mathrm{dL}$ hari ke $710,484 \mathrm{gr} / \mathrm{dL}$ hari ke 14 10,817gr/dL IMT terbanyak adalah IMT Ideal 21 responden $(70,0 \%) \%)$ dengan mean hari ke 1 $10,248 \mathrm{gr} / \mathrm{dL}$ hari ke $7 \quad 10,462 \mathrm{gr} / \mathrm{dL}$ hari ke 14 10,810r/dL, pendidikan terbanyak adalah pendidikan tinggi (SMA-Perguruan Tinggi) 
JKM (Jurnal Kebidanan Malahayati),Vol 7,No.4.Oktober 2021,

ISSN (Print) 2476-8944 ISSN (Online) 2579-762X, Hal 772-779

sebanyak 25 responden $(83,3 \%) \%)$ dengan mean hari ke 1 10,268gr/dL hari ke 7 10,480gr/dL hari ke 14 10,812gr/dL dan pekerjaan rata-rata bekerja 15 responden $(50,0 \%) \%)$ dengan mean hari ke 1 $10,220 \mathrm{gr} / \mathrm{dL}$ hari ke $7 \quad 10,453 \mathrm{gr} / \mathrm{dL}$ hari ke 14 $10,773 \mathrm{gr} / \mathrm{dL}$

Tabel 2.

Rata-Rata Karakteristik Ibu Hamil di Praktik Mandiri BidanOkdiah Betty, Amd. Keb Kec.Trimurjo Kab.Lampung Tengah Tahun 2021

\begin{tabular}{|c|c|c|c|c|c|c|}
\hline \multirow{2}{*}{ Karakteristik } & \multirow{2}{*}{ Frekuensi } & \multirow{2}{*}{ Persentase } & \multicolumn{3}{|c|}{ Mean } & \multirow{2}{*}{ P-Value } \\
\hline & & & Hari 1 & Hari 7 & Hari 14 & \\
\hline \multicolumn{7}{|l|}{ Usia } \\
\hline$<20$ dan $>35$ Tahun & 6 & 20,0 & 10,275 & 10,492 & 10,804 & \multirow{3}{*}{0,000} \\
\hline 20-35 Tahun & 24 & 80,0 & 10,250 & 10,433 & 10,817 & \\
\hline \multicolumn{6}{|l|}{ Usia Kehamilan } & \\
\hline TM I & 12 & 40,0 & 10,258 & 10,475 & 10,792 & \multirow{3}{*}{0,000} \\
\hline TM II & 18 & 60,0 & 10,278 & 10,483 & 10,817 & \\
\hline \multicolumn{6}{|l|}{ IMT } & \\
\hline IMT Ideal & 21 & 70,0 & 10,248 & 10,462 & 10,810 & \multirow{3}{*}{0,000} \\
\hline IMT Tidak Ideal & 9 & 30,0 & 10,322 & 10,522 & 10,800 & \\
\hline \multicolumn{6}{|l|}{ Pendidikan } & \\
\hline Pendidikan Tinggi & 25 & 83,3 & 10,268 & 10,480 & 10,812 & \multirow{2}{*}{0,000} \\
\hline \multicolumn{2}{|l|}{ Pekerjaan } & 16,7 & 10,280 & 10,480 & 10,780 & \\
\hline Ibu Tidak Bekerja & 15 & 50,0 & 10,220 & 10,453 & 10,773 & \multirow{2}{*}{0,000} \\
\hline Ibu Bekerja & 15 & 50,0 & 10,320 & 10,507 & 10,840 & \\
\hline Total & 30 & 100 & - & - & - & - \\
\hline
\end{tabular}

Analisa Univariat

$\mathrm{Hb}$ Pretes

Tabel 3.

Rata-Rata Kadar HB Pada Ibu Hamil Sebelum Diberi Sari Kurma Di Praktik Mandiri Bidan Okdiah Betty, Amd. Keb Kec.Trimurjo Kab.Lampung Tengah Tahun 2021

\begin{tabular}{|c|c|c|c|c|c|}
\hline Variabel & N & Mean & SD & SE & Min-Max \\
\hline Hb Hari Ke 1 & 30 & 10,270 & 0,4481 & 0,0818 & $9,3-10,8$ \\
\hline
\end{tabular}

Dari tabel diatas dapat diketahui bahwa ratarata kadar HB pada ibu hamilsebelum diberi sari kurma di Praktik Mandiri BidanOkdiah Betty, Amd. Keb Kec.Trimurjo Kab.Lampung Tengah Tahun 2021,dengan Mean10, 270gr/dlnilai min 9,3gr/dl dan nilai $\max 10,8 \mathrm{gr} / \mathrm{dl}$.

Dari tabel dibawah dapat diketahui bahwa rata-rata kadar HB pada ibu hamilpada hari ke 7 dan 14 sesudah diberi sari kurma di Praktik Mandiri Bidan Okdiah Betty, Amd. Keb Kec.Trimurjo Kab.Lampung Tengah Tahun 2021, Hb hari ke 7 dengan Mean10,480gr/dlnilai min 9,7gr/dl dan nilai $\max 11,0 \mathrm{gr} / \mathrm{dl}$, dan $\mathrm{Hb}$ hari ke 14 dengan Mean10,807gr/dlnilai min 10,2gr/dl dan nilai max $11,2 \mathrm{gr} / \mathrm{dl}$.

Tabel 4.

Rata-Rata Kadar HB Pada Ibu HamilSesudah Diberi Sari Kurma Di Praktik Mandiri Bidan Okdiah Betty, Amd. Keb Kec.Trimurjo Kab.Lampung Tengah Tahun 2021

\begin{tabular}{|l|c|c|c|c|c|}
\hline \multicolumn{1}{|c|}{ Variabel } & N & Mean & SD & SE & Min-Max \\
\hline Hb Hari Ke 7 & 30 & 10,480 & 0,3943 & 0,0720 & $9,7-11,0$ \\
\hline Hb Hari Ke 14 & 30 & 10,807 & 0,2912 & 0,0532 & $10,2-11,2$ \\
\hline
\end{tabular}


Analisis Bivariat

Tabel 5.

Pengaruh Pemberian Sari Kurma Terhadap Peningkatan Kadar HB Pada Ibu HamilDi Praktik Mandiri BidanOkdiah Betty,Amd. Keb Kec.Trimurjo Kab.Lampung Tengah Tahun 2021

\begin{tabular}{lccccc}
\hline \multicolumn{1}{c}{ Variabel } & N & Mean & SD & SE & P -Value \\
\hline Hb Hari Ke 1 & 30 & 10,270 & 0,4481 & 0,0818 & \\
Hb Hari Ke 7 & 30 & 10,480 & 0,3943 & 0,0720 & 0,000 \\
Hb Hari Ke 14 & 30 & 10,807 & 0,2912 & 0,0532 & \\
\hline
\end{tabular}

Dari tabel terlihat bahwa rata-rata kadar $\mathrm{HB}$ pada ibu hamilsebelum diberi sari kurma di Praktik Mandiri BidanOkdiah Betty, Amd. Keb Kec.Trimurjo Kab.Lampung Tengah Tahun 2021,dengan Mean10, 270gr/dl, $\mathrm{Hb}$ hari ke 7 dengan Mean10,480gr/dldan $\mathrm{Hb}$ hari ke 14 dengan Mean10,807gr/dl, dari pemaparan tersebut dapat dilihat jika $\mathrm{Hb}$ ibu hamil mengalami peningkatan pada pengukuran hari ke 1,7 dan 14 .

Hasil uji statistik didapatkan nilai $P$-value $=$ $0.000(<0,05)$ yang artinya terdapat pengaruh pemberian sari kurma terhadap peningkatan kadar $\mathrm{Hb}$ pada ibu hamildi Praktik Mandiri BidanOkdiah Betty,Amd.KebKec.Trimurjo Kab.Lampung Tengah Tahun 2021.

\section{PEMBAHASAN}

\section{Analisis Univariat}

Rata-Rata Kadar HB Pada Ibu Hamil Sebelum Diberi Sari Kurma Di Praktik Mandiri BidanOkdiah Betty, Amd. Keb Kec.Trimurjo Kab.Lampung Tengah Tahun 2021

Rata-rata kadar HB pada ibu hamilsebelum diberi sari kurma di Praktik Mandiri BidanOkdiah Betty, Amd. Keb Kec.Trimurjo Kab.Lampung Tengah Tahun 2021,dengan Mean10, 270gr/dlnilai $\min 9,3 \mathrm{gr} / \mathrm{dl}$ dan nilai max $10,8 \mathrm{gr} / \mathrm{dl}$.

Sejalan dengan penelitian yang dilakukan oleh Widowati (2019)Pengaruh Pemberian Sari Kurma Terhadap Peningkatan Kadar Hemoglobin Ibu Hamil. Hasil penelitian menunjukkan rata-rata kadar hemoglobin sebelum pemberian sari kurma sebesar 9,6 gr/dL,

Sejalan dengan teori Manuaba (2010)Anemia ialah keadaan dimana massa eritrosit dan/atau massa hemoglobin yang beredar tidak dapat memenuhi fungsinya untuk menyediakan oksigen bagi jaringan tubuh. Secara laboratorik dijabarkan sebagai penurunan di bawah normal kadar hemoglobin hitung eritrosit dan hematokrit (packed red cell) Kurang dari normal. Anemia merupakan keadaan menurunnya kadar haemoglobin, hematokrit, dan jumlah sel darah merah di bawah $11 \mathrm{gr} / \mathrm{dl}$.
Pada beberapa orang, pemberian tablet zat besi dapat menimbulkan gejala-gejala seperti mual, nyeri didaerah lambung, kadang terjadi diare dan sulit buang air besar, pusing bau logam (Bakta, 2017

Menurut Proverawati (2011) Gejala awal biasanya tidak ada atau tidak spesifik (misalnya, kelelahan, kelemahan, pusing, dispnea ringan dan tenaga). Gejala dan tanda lain mungkin termasuk pucat dan,jika terjadi anemia berat,akan mengalami takikardia atau hipotensi

Menurut peneliti anemia adalah kondisi dimana kadar $\mathrm{Hb}$ ibu dibawah dari normal. Kandungan $\mathrm{Hb}$ yang rendah dapat mengindekasikan anemia, dengan gejala berupa lemah, kurang nafsu makan, kurang energi, konsenstrasi menurun, sakit kepala, mudah trinfeksi penyakit, mata kunang-kunang, selain itu kelopak mata,bibir, dan kuku tampak pucat.Penyebab tersering anemia selama kehamilan yaitu defisiensi besi dan kehilangan darah akut. Tidak jarang keduanya saling berkaitan erat, karena pengeluaran darah yang berlebihan disertai hilangnya besi hemoglobin dan terkurasnya simpanan besi pada suatu kehamilan dapat menjadi penyebab penting anemia defisiensi besi pada kehamilan berikutnya. Status gizi yang kurang sering berkaitan dengan anemia defisiensi besi

Rata-Rata Kadar HB Pada Ibu HamilSesudah Diberi Sari Kurma Di Praktik Mandiri Bidan Okdiah Betty, Amd. Keb Kec.Trimurjo Kab.Lampung Tengah Tahun 2021

Rata-rata kadar HB pada ibu hamilpada hari ke 7 dan 14 sesudah diberi sari kurma di Praktik Mandiri Bidan Okdiah Betty, Amd. Keb Kec.Trimurjo Kab.Lampung Tengah Tahun 2021, Hb hari ke 7 dengan Mean10,480 gr/dlnilai min 9,7gr/dl dan nilai $\max 11,0 \mathrm{gr} / \mathrm{dl}$, dan $\mathrm{Hb}$ hari ke 14 dengan Mean10,807gr/dlnilai min 10,2gr/dl dan nilaii max $11,2 \mathrm{gr} / \mathrm{dl}$.

Sejalan dengan penelitian yang dilakukan oleh Widowati (2019) Pengaruh Pemberian Sari Kurma Terhadap Peningkatan Kadar Hemoglobin Ibu Hamil. Hasil penelitian menunjukkan rata-rata 


\section{JKM (Jurnal Kebidanan Malahayati),Vol 7,No.4.Oktober 2021, ISSN (Print) 2476-8944 ISSN (Online) 2579-762X, Hal 772-779}

kadar hemoglobin sebelum pemberian sari kurma sebesar 9,6 gr/dL, sedangkan sesudah pemberian sari kurma selama 10 hari rata-rata sebesar 10,6 $\mathrm{gr} / \mathrm{dL}$.

Sejalan dengan teori Manuaba (2010) dikatakan anemia bila kadar $\mathrm{Hb}$ pada wanita hamil trimester $\mid<11 \mathrm{gr} / \mathrm{dl}$, trimester $\|<10,5 \mathrm{gr} / \mathrm{dl}$ dan trimester $\mathrm{III}<10 \mathrm{gr} / \mathrm{dl}$. Kadar $\mathrm{Hb}$ ibu hamil terjadi jika produksi sel darah merah meningkat, nilai normal haemoglobin (12 sampai $16 \mathrm{gr} / \%$ ) dan nilai normal hematokrit ( $37 \%$ sampai $47 \%$ ) menurun secara menyolok. Penurunan lebih jelas terlihat selama trimester kedua, saat terjadi ekspansi volume darah yang cepat. Apabila nilai hematokrit turun sampai $35 \%$ atau lebih, wanita dalam keadaan anemia (Benson, 2009). Kadar Hb pada darah dikatakan anemia apabila kadar $\mathrm{Hb}$ dasar pada pria $<13 \mathrm{gr} / \%$, wanita $<12 \mathrm{gr} / \%$ dan pada ibu hamil $<11 \mathrm{gr} / \%$

Pada penelitian ini didapat nilaii kadar $\mathrm{Hb}$ setelah diperlakuan dengan menggunakan sari kurma mengalami peningkatan rata-rata $\mathrm{Hb}$ dengan selisih skor 0,2-1,4gr/dl pada 14 hari intervensi. Hal ini dikarenakan keteraturan ibu saat mengkonsumsi sari kurma menjadi penyebab penting anemiadefisiensi besi pada kehamilan berikutnya.Sari kurma yang kaya akan kandungannya,mengandung komponen-komponen yang mampumeningkatkan penyerapan zat besi atau berperan dalam pembentukan sel darah merah tempat hemoglobin berada. Sari kurma mengandung berbagai vitamin, mineral, antioksidan dll.

Kenaikan volume darah selama kehamilan akan meningkatkan kebutuhan $\mathrm{Fe}$ atau Zat Besi. Jumlah Fe pada bayi baru lahir kira-kira 300mg dan jumlah yang diperlukan ibu untuk mencegah anemia akibat meningkatnya volume darah adalah $500 \mathrm{mg}$. Selama kehamilan seorang ibu hamil menyimpan zat besi kurang lebih $1.000 \mathrm{mg}$ termasuk untuk keperluan janin, plasenta dan hemoglobin ibu sendiri. Sedangkan kebutuhan sebelum hamil atau kondisi normal kira-kira $26 \mathrm{mg}$ per hari (Umur 20-45 tahun), dewasa $15 \mathrm{mg} / \mathrm{hari}$, dan ibu hamil 30 $\mathrm{mg} /$ hari (Sukarni, 2019).

\section{Analisa Bivariat}

Pengaruh Pemberian Sari Kurma Terhadap Peningkatan Kadar HB Pada Ibu Hamil Di Praktik Mandiri Bidan Okdiah Betty,Amd. Keb Kec.Trimurjo Kab.Lampung Tengah Tahun 2021

Rata-rata kadar HB pada ibu hamilsebelum diberi sari kurma di Praktik Mandiri BidanOkdiah Betty, Amd. Keb Kec.Trimurjo Kab.Lampung Tengah Tahun 2021,dengan Mean10, 270gr/dl, Hb hari ke 7 dengan Mean10,480gr/dldan Hb hari ke 14 dengan Mean10,807gr/dl, dari pemaparan tersebut dapat dilihat jika $\mathrm{Hb}$ ibu hamil mengalami peningkatan pada pengukuran hari ke 1,7 dan 14 .

Hasil uji statistik didapatkan nilai $P$-value $=$ $0.000 \quad(<0,05)$ yang artinya terdapat pengaruh pemberian sari kurma terhadap peningkatan kadar $\mathrm{Hb}$ pada ibu hamildi Praktik Mandiri BidanOkdiah Betty,Amd.KebKec.Trimurjo Kab.Lampung Tengah Tahun 2021.

Sejalan dengan hasil penelitian Widowati (2019) Pengaruh Pemberian Sari Kurma Terhadap Peningkatan Kadar Hemoglobin Ibu Hamil. Hasil penelitian menunjukkan rata-rata kadar hemoglobin sebelum pemberian sari kurma sebesar 9,6 gr/dL, sedangkan sesudah pemberian sari kurma selama 10 hari rata-rata sebesar 10,6 gr/dL. Ada pengaruh yang signifikan ( $p$ value $0,004<0,05$ ) pemberian sari kurma dengan kadar hemoglobin ibu hamil dengan anemia. Namun demikian hasil pengujianlaboratorium diketahui kadar zat besi pada sari kurma rendah.

Sejalan dengan pendapat yang dikemukakan oleh Wulandari (2019)Pemenuhan nutrisi dalam meningkatkan $\mathrm{Hb}$ pada Ibu Hamil didapatkan dalam daging, buah-buahan serta sayuran dan buah salah satunya adalah kurma. Tidak seperti kebanyakan buah lainnya kadar zat besi dalam buah kurma cukup tinggi yaitu $1,2 \mathrm{mg} / 1000 \mathrm{gr}$ buah kurma, dimana zat besi menjadi salah satu komponen dalam darah untuk membawa oksigen dalam darah

Hemoglobin merupakan kompleks protein yang terdiri dari heme yang mengandung besi dan globin dengan interaksi di antara heme dan globin yang menyebabkan Hemoglobin $(\mathrm{Hb})$ merupakan yang ireversibel untuk mengangkut oksigen. Zat besi bersama dengan protein (globin) dan protoporfirin mempunyai peranan penting dalam pembentukan hemoglobin (Natalia, 2015).

Pada penelitian ini rata-rata kadar HB pada ibu hamilsebelum diberi sari kurma di Praktik Mandiri BidanOkdiah Betty, Amd. Keb Kec.Trimurjo Kab.Lampung Tengah Tahun 2021, dengan Mean10, 270gr/dl, $\mathrm{Hb}$ hari ke 7 dengan Mean10,480gr/dldan $\mathrm{Hb}$ hari ke 14 dengan Mean10,807gr/dl, dari pemaparan tersebut dapat dilihat jika $\mathrm{Hb}$ ibu hamil mengalami peningkatan pada pengukuran hari ke 1,7 dan 14.

Karakteristik ibu hamil di Praktik Mandiri BidanOkdiah Betty, Amd. Keb Kec.Trimurjo Kab.Lampung Tengah Tahun 2021, dengan melihat usia terbanyak adalah usia 20-35 tahun sebanyak 24 responden $(80,0 \%)$ dengan mean hari ke 1 $10,275 \mathrm{gr} / \mathrm{dL}$ hari ke 7 10,942gr/dL hari ke 14 $10,804 \mathrm{gr} / \mathrm{dl}$ 
Usia kehamilan terbanyak adalah TM II 1527 Minggu sebanyak 18 responden $(60,0 \%)$ dengan mean hari ke 1 10,278gr/dl hari ke 7 10,484gr/dl hari ke 14 10,817gr/dl. Hal ini terkait dengan Kondisi biologis dan psikologis dari ibu hamil. Sebaliknya pada kelompok umur $<20$ tahun beresiko anemia sebab pada kelompok umur tersebut perkembangan bilogis yaitu reproduksi belum optimal. Selain itu, kehamilan pada kelompok usia diatas 35 tahun merupakan kehamilan yang beresiko tinggi. Wanita hamil dengan umur diatas 35 tahun juga akan rentan anemia. Hal ini menyebabkan daya tahun tubuh mulai menurun dan mudah terkena berbagai infeksi selama masa kehamilan

IMT terbanyak adalah IMT Ideal 21 responden $(70,0 \%) \%)$ dengan mean hari ke 1 $10,248 \mathrm{gr} / \mathrm{dl}$ hari ke 7 10,462gr/dl hari ke 14 10,810r/dl, Faktor pengukuran LILA yang tidak berhubungan dengan anemia memungkinkan carapengukuran yang tidak tepat, faktor dari pekerjaan ibu hamil, dan pola makan ibuyang tidak baik atau bisa dilihat dari jumlah anak yang terlalu banyak sehingga kebutuhan ibu hamil tidak terpenuhi. Gizi kurang pada ibu hamil dapat menyebabkan resiko dan komplikasi pada ibu antara lain : anemia, perdarahan, berat badan ibu tidak bertambah secara normal, dan terkena penyakitinfeksi.

Pendidikan terbanyak adalah pendidikan tinggi (SMA-Perguruan Tinggi) sebanyak 25 responden $(83,3 \%) \%)$ dengan mean hari ke 1 $10,268 \mathrm{gr} / \mathrm{dL}$ hari ke $7 \quad 10,480 \mathrm{gr} / \mathrm{dL}$ hari ke 14 $10,812 \mathrm{gr} / \mathrm{dL}$. Pendidikan yang dijalani seseorang memiliki pengaruh pada peningkatan kemampuan berpikir, dengan kata lain seseorang yang berpendidikan lebih tinggi akan dapat mengambil keputusan yang lebih rasional, umumnya terbuka untuk menerima perubahan atau hal baru dibandingkan dengan individu yang berpendidikan rendah. Tingkat pendidikan ibu hamil yang rendah mempengaruhi penerimaan informasi sehingga pengetahuan tentang anemia dan faktorfaktor yang berhubungan dengannya menjadi terbatas, terutama pengetahuan tentang pentingnya zat besi.

Pekerjaan rata-rata bekerja 15 responden $(50,0 \%) \%)$ dengan mean hari ke $110,220 \mathrm{gr} / \mathrm{dL}$ hari ke 7 10,453gr/dL hari ke 14 10,773gr/dl. Dalam hal kejadian anemia pada ibu hamil berdasarkan pekerjaan tampak persentase lebih besar pada ibu hamil yang bekerja. Pekerjaan merupakan suatu aktivitas sehingga memperoleh penghasilan. Jenis pekerjaan menentukan jumlah penghasilan yang diterima. Ibu hamil yang bekerja berarti mempunyai penghasilan untuk membantu suami dalam mencukupi kebutuhan sehari-hari. Ibu hamil yang mempunyai penghasilan berhubungan dengan kemampuan ibu hamil untuk memperoleh pengetahuan tentang anemia karena tercukupi keuangan keluarga. Rendahnya tingkat ekonomi pada ibu hamil yang tidak bekerja mengakibatkan kemampuan ibu hamil untuk memperoleh informasi dan melakukan pemeriksaan kehamilan menjadi berkurang.(Mariza, 2016). Namun, disisi lain ibu hamil yang tidak bekerja mempunyai lebih banyak waktu luang sehingga dapat digunakan untuk mengikuti berbagai penyuluhan meskipun mempunyai keterbatasan dalam hal keuangan. Pengetahuan yang diperoleh ibu hamil tidak bekerja ini berpengaruh terhadap rendahnya kejadian anemia ibu hamil dibanding ibu yang bekerja.

Berdasarkan hasil diatas dapat diketahui jika sari kurma dapat membantu peningkatan $\mathrm{Hb}$ pada ibu hamil, dengan rata-rata peningkatan per minggu 0,2-1,4 per minggu, hal ini sesuai dengan pendapat M. A. Rahayu et al (2016) Kurma mengandung nutrisi yang amat baik. Kandungan gula yang terdapat di dalam buah kurma dapat langsung diserap oleh tubuh. Kandungan gula dalam buah ini berbeda dengan kandungan gula dalam makanan yang lain, sebab kandungan gula yang biasanya harus diuraikan terlebih dahulu baru diserap oleh tubuh. Para pakar diet menilai kurma sebagai makanan terbaik bagi wanita hamil dan ibu menyusui. Bahwa pengaruh pemberian kurma terhadap kemajuan persalinan, bagi ibu hamil untuk mengkonsumsi buah kurma dalam jumlah dan saat yang tepat.

Kurma mengandung karbohidrat tinggi sehingga dapat menyediakan energi yang cukup. Sebagian kandungan gulanya terdiri atas glukosa, fruktosa, dan sukrosa,. Menurut data kementerian kesehatan haji menjelaskan bahwa kadar zat besi dalam buah kurma juga cukup tinggi yaitu $0,90 \mathrm{mg} / 100 \mathrm{~g}$ buah kurma ( $11 \% \mathrm{AKG})$, dimana zat besi menjadi salah satu komponen dalam darah untuk membawa oksigen dalam darah, untuk menjaga keseimbangan zat besi dalam tubuh, sehingga mengurangi resiko terjadinya perdarahan pada ibu hamil (Diyah, 2017).

Vitamin C yang terkandung dalam sari kurma juga dapat meningkatkan penyerapan besi terutama dengan mereduksi besi ferri menjadi besi ferro. Selain dari perannya dalam pengubah Ferri menjadi Ferro sebelum penyerapan usus, vitamin $C$ juga mengatur homeostasis besi dengan menghambat ekspresi hepcidin (misalnya, dalam sel HepG2), menjadikan vitamin $\mathrm{C}$ berpotensi membantu melemahkan defisiensi besi. Adapun metabolisme vitamin A yang terdapatpada sari kurmamemiliki 


\section{JKM (Jurnal Kebidanan Malahayati),Vol 7,No.4.Oktober 2021, \\ ISSN (Print) 2476-8944 ISSN (Online) 2579-762X, Hal 772-779}

implikasi terhadap homeostasis zat besi, sehingga kekurangan vitamin A dapat menyebabkan defisiensi zat besi (Widowati, 2019)

\section{SIMPULAN}

Ada pengaruh pemberian sari kurma terhadap peningkatan kadar $\mathrm{Hb}$ pada ibu hamildi Praktik Mandiri BidanOkdiah Betty,Amd. Keb Kec.Trimurjo Kab.Lampung Tengah Tahun 2021 dengan nilai P-Value 0,000 .

\section{SARAN}

Diharapkan bagi masyarakat dan ibu hamil yang mengalami anemia,menganjurkan ibu hamil mengkonsumsi sari kurma sebanyak $10 \mathrm{ml}$ diminum sebanyak tiga kali sehari agar dapat meningkatkan kadar $\mathrm{Hb}$ pada ibu hamil. Serta mengkonsumsi makanan yang mengandung zat besi serta konsumsi makanan yang kaya akan gizi dan mengandung vitamin c seperti sari kurma.

\section{DAFTAR PUSTAKA}

Arisman. (2010). Gizi dalam Daur Kehidupan: Buku Ajar IImu Gizi. Jakarta:EGC.

Arum Sari,Eti Poncorini Pamungkasari \& Yulia Lanti Retno Dewi (2018) The Addition Of Dates Palm (Phoenix Dactylifera)On Iron Supplementation $(\mathrm{Fe})$ Increases the Hemoglobin Level Of Adolescent Girls With Anemia

Bakta. (2017). Hematologi Klinik Ringkas. Jakarta: EGC.

Diyah, S. M. (2017). Perbedaan Kadar Hemoglobin (Hb) Mengqunakan Alat BGA dan Automatic Hematology Analyzer Pada Pasien Gagal Ginjal Kronis (Doctoral dissertation, Universitas Muhammadiyah Surabaya).

Eny. S., Pratamaningtyas, S., \& Panggayuh, A. (2016). Pengaruh Konsumsi Kurma (Phoenix Dactylifera) Terhadap Kenaikan Kadar Hemoglobin Pada Ibu Hamil Trimester li Di Wilayah Puskesmas Kediri. Jurnal IImu Kesehatan, 5(1), 96-104.

Kadek Ayu Ida \& Maternity Dainty Hubungan Konsumsi Tablet Besi (FE) dengan Kejadian Anemia di Bidan Praktek Swasta (BPS) Nengah Astiti Sidorejo Lampung

Kemenkes.(2018).profilsehat indonesia.

Manuaba, IBG. (2010). IImu Kebidanan, Penyakit Kandungan dan Keluarga Berencana Untuk Pendidikan Bidan. Jakarta: EGC.

Manuaba, IBG. (2014). IImu Kebidanan, Penyakit Kandungan dan Keluarga Berencana Untuk Pendidikan Bidan. Jakarta: EGC.
Mariza, A. (2016). Hubungan pendidikan dan sosial ekonomi dengan kejadian anemia pada ibu hamil di BPS T Yohan Way Halim Bandar Lampung tahun 2015. Holistik Jurnal Kesehatan, 10(1), 5-8.

Notoatmojo,S. (2018). Metodelogi Penelitian Kesehatan Rineka Cipta: Jakarta.

Profil Dinas Kesehatan Provinsi Lampung. (2017). Angka Anemia.

Proverawati A. (2011). Buku Anemia dan Anemia Kehamilan .Yogyakarta.

Rahayu, M. A., Nugraheni, G., \& Rahayu, S. (2016). Pengaruh Pemberian Buah Kurma Kering (Tamr) Mulai Usia Kehamilan $37 m g$ Terhadap Kemajuan Proses Persalinan Pada Ibu Bersalin Di Rumah Bersalin G Bekasi.Health Science Growth (HSG) Journal, 1(1).

Rahayu, R. D. (2017).Efektivitas Penambahan Sari Kurma Dalam Pemenuhan Gizi Ibu Hamil Anemia Di Puskesmas Wedi, Kabupaten Klaten. Jurnal Kebidanan Dan Kesehatan Tradisional, 2(2).

Rukiyah, Ai, Yeyeh. (2019) Asuhan Kebidanan Patologi Kebidanan 4.Jakarta: Trans Infomedia.

Sukarni, Icesmi. (2019). Kehamilan Persalinan Dan Nifas.Yogyakarta: Nuha Media..

Wasnidar, T. (2013). Anemia Pada lbu Hamil Konsep. Jakarta: TIM.

Widowati, R., Kundaryanti, R., \& Lestari, P. P. (2019). Pengaruh Pemberian Sari Kurma Terhadap Peningkatan Kadar Hemoglobin Ibu Hamil. Jurnal Al-Azhar Indonesia Seri Sains dan Teknologi, 5(2), 60-65.

Wirjatmadi,B.,\& Andriani, M. (2012). Peranan gizi dalam siklus kehidupan, prenamedia Group, Jakarta

Wulandari, W., Siregar, Y., Irianti, E., \& Hasibuan, Y. (2019). Efektifitas Pemberian Ekstrak Kurma Terhadap Peningkatan Kadar Hemoglobin Ibu Hamil Trimester lii Di Klinik Sumiariani Dan Klinik Pratama Sari Tahun 2019

Yulita, N., \& Febriani, A. (2020). Efektifitas Sari Kurma Dalam Peningkatan $\mathrm{Hb}$ lbu Hamil Di Kota Pekanbaru. In CALL FOR PAPER SEMINAR NASIONAL KEBIDANAN (Vol. 1, No. 1, pp. 27-33).

Yuviska, I. A., \& Yuliasari, D. (2019). PENGARUH PEMBERIAN KURMA TERHADAP PENINGKATAN KADAR HEMOGLOBIN PADA IBU HAMIL DENGAN ANEMIA DI PUSKESMAS RAJABASA INDAH BANDAR LAMPUNG. JKM (Jurnal Kebidanan Malahayati), $\quad$ 5(4), 343-348. 